\title{
PENGARUH DESAIN PRODUK DAN GAYA HIDUP TERHADAP KEPUTUSAN PEMBELIAN KAOS DISTRO HEURAS GENGGERONG
}

\author{
THE EFFECT OF PRODUCT DESIGN AND LIFESTYLE ON THE \\ PURCHASE DECISION OF HEURAS GENGGERONG T-shirts
}

\author{
Abdul Fatah'), Dhiyaul Haq Jundullah' ${ }^{2)}$, Julia Valdah Ariany Abdillah ${ }^{3)}$, Jijah Hilyatul \\ Ajijah $^{4}$ \\ ${ }^{1,2,3,4)}$ Prodi Manajemen,Universitas Singaperbangsa Karawang \\ Jl.HS.Ronggo Waluyo,Puseurjaya, Kec. Telukjambe Timur, Karawang, Jawa Barat 41361 \\ abdulfatah842@gmail.com, jundijundullah234@gmail.com, juliavaldah.6@gmail.com dan \\ jijahhilyatul@gmail.com
}

\begin{abstract}
ABSTRAK
Distro Heuras Genggerong merupakan industri kreatif dalam bidang fashion. Persaingan semakin ketat antar distro yang ada di Karawang membuat distro Heuras Genggerong harus menghadapi tantangan yang serius dari para pesaingnya, karena adanya kesamaan dalam produk yang ditawarkan. Penelitian ini bertujuan untuk mengetahui pengaruh desain produk dan gaya hidup terhadap keputusan pembelian kaos Distro Heuras Genggerong.

Dalam penelitian ini penulis menggunakan metode deskriptif dan verifikatif dengan teknik insidental sampling terhadap 100 responden. Jenis pengumpulan data melalui kuesioner, wawancara, observasi, dan studi pustaka. Kualitatif dan kuantitatif merupakan teknik analisis yang digunakan oleh penulis. Diketahui bahwa hasil analisis statistik desain produk dan gaya hidup berpengaruh positif dan signifikan terhadap keputusan pembelian. Antara desain produk dan gaya hidup berpengaruh secara simultan terhadap keputusan pembelian sebesar $73,7 \%$ dan untuk 26,3\% dipengaruhi oleh variabel lain. Dapat disimpulkan dari hasil tersebut bahwa desain produk dan gaya hidup mempunyai pengaruh terhadap keputusan pembelian secara parsial maupun simultan.
\end{abstract}

Kata kunci: desain produk, gaya hidup, keputusan pembelian

\begin{abstract}
Heuras Genggerong distro is a creative industry in the fashion sector. The tighter competition between the existing distributions in Karawang has made the Heuras Genggerong distro face serious challenges from its competitors, because of the similarities in the products offered. This study aims to determine the effect of product design and lifestyle on purchasing decisions for Heuras Genggerong Distro t-shirts.

In this study the authors used descriptive and verification methods with incidental sampling techniques to 100 respondents. The types of data collection through questionnaires, interviews, observation, and literature study. Qualitative and quantitative are analytical techniques used by the author. It is known that the results of statistical analysis of product design and lifestyle have a positive and significant effect on purchasing decisions. Between product design and lifestyle, the effect simultaneously on purchasing decisions is $73.7 \%$ and for $26.3 \%$ it is influenced by other variables. It can be concluded from these results that product design and lifestyle have an influence on purchasing decisions partially or simultaneously.
\end{abstract}

Keywords: product design, lifestyle, purchasing decisions 


\section{SEGMEN Jurnal Manajemen dan Bisnis \\ Volume 17 No 2 juli 2021 \\ p-ISSN: 0216-938X e-ISSN: 2684-8414}

\section{PENDAHULUAN}

Pertumbuhan ekonomi nasional tidak terlepas dari kontribusi signifikan yang diberikan sektor ekonomi kreatif. Sektor ini menyumbang 7,38\% terhadap PDB nasional atau sekitar 852 triliun rupiah, tenaga kerja yang terserap sebanyak 15,9 juta $(13,90 \%)$ dan nilai ekspor mencapai US $\$ 19,4$ miliar $(12,88 \%)$ pada tahun 2015. Hal ini membuktikan bahwa Ekonomi Kreatif memiliki potensi untuk berkembang dimasa mendatang. Dari 16 subsektor industri kreatif Indonesia, industri fashion menduduki peringkat kedua dengan menyumbang 18,15\% nilai tambah bruto. (sumber : Badan Ekonomi Kreatif)

Industri kaos distro tergolong kepada industri kreatif dalam bidang fashion. Pada masa sekarang perusahaan banyak yang berfungsi sebagai distro dan mendistribusikan kebutuhan pakaian berbagai kalangan. Dengan banyaknya distro atau clothing, maka bisa dikatakan bahwa konsumen memiliki banyak pilihan untuk berbelanja. Untuk dapat bertahan dalam bisnis ini, tentu saja harus menetapkan suatu strategi yang tepat dengan tidak membelakangkan apa yang menjadi kebutuhan dan keinginan konsumen.

Di karawang sendiri telah terdapat banyak distro, seperti dikutip dari laman www.karawangkita.com diantaranya yaitu G-Block Real Clothing, Distro Alibi, Distro Heuras Genggerong, dan Distro Mars. Disini peneliti ingin mengambil objek Distro Heuras Genggerong. Distro Heuras Genggerong merupakan distro yang menghasilkan produk kaos, dompet, topi, dan aksesoris lainnya.
Persaingan yang tinggi antar distro yang ada di Karawang membuat distro Heuras Genggerong kini harus menghadapi tantangan yang serius dari para pesaingnya, karena adanya kesamaan dalam produk yang ditawarkan. Maka dari itu, penggunaan strategi yang tepat akan sangat berpengaruh terhadap tingkat penjualan yang akan didapatkan.

Dari grafik 1 dapat bisa kita lihat bahwa penjualan di Distro Heuras Genggerong tidak selalu menunjukkan tren positif dalam penjualannya, pada bulan tertentu penjualannya mengalami penurunan meskipun tidak signifikan. Pada bulan Juni sangat terlihat sekali kenaikan dari penjualan di Distro Heuras Genggerong, kenaikan ini bukan tanpa alasan melainkan adanya hari raya idul fitri yang membuat masyarakat cenderung untuk membeli pakaian baru.

Model perilaku konsumen dengan menetapkan tiga faktor yang berpengaruh terhadap perilaku konsumen dikembangkan oleh Assael (1995) dalam Sodik (2004). Stimuli merupakan faktor pertama yang berpengaruh pada konsumen, penerimaan informasi oleh konsumen dan pemrosesan informasi terjadi saat konsumen mengevaluasi informasi dari periklanan, teman atau dari pengalaman sendiri ditunjukkan oleh stimuli. Karakteristik pribadi konsumen meliputi persepsi, sikap, manfaat serta karakteristik konsumen (demografi, kepribadian, gaya hidup) merupakan pengaruh kedua. Pengaruh berikutnya merupakan respon konsumen yang merupakan hasil akhir dari proses keputusan konsumen dan suatu pertimbangan 


\section{SEGMEN Jurnal Manajemen dan Bisnis \\ Volume 17 No 2 juli 2021 \\ p-ISSN: 0216-938X e-ISSN: 2684-8414}

yang menyeluruh dari semua faktor diatas. motif-motif dalam melakukan pembelian Faktor ini berasal dari internal individu, juga termasuk dalam faktor ini.

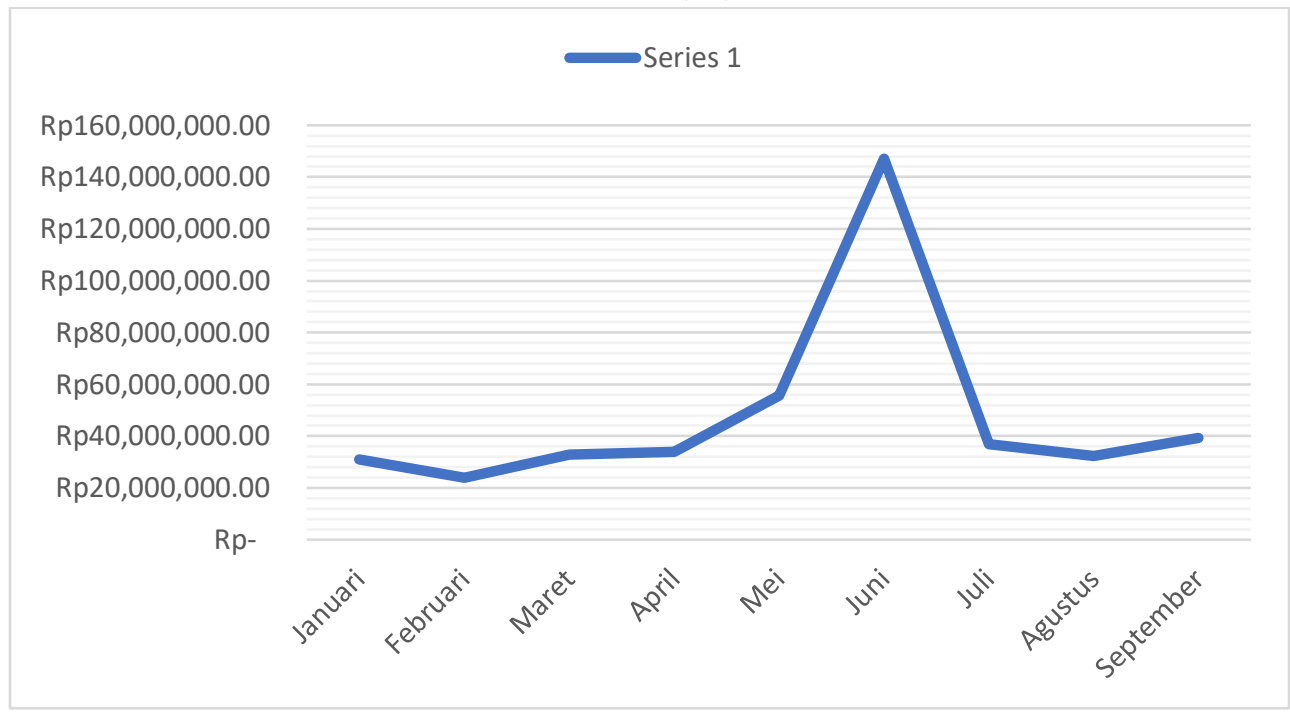

Grafik 1

Hasil Penjualan di Distro Heuras Genggerong

(Sumber : Distro Heuras Genggerong)

Keputusan pembelian sebagai sebuah proses dimana konsumen mengenal masalahnya, mencari informasi mengenai produk atau merek tertentu dan mengevaluasi seberapa baik masingmasing alternatif tersebut dapat memecahkan masalahnya yang kemudain mengarah kepada keputusan pembelian menurut Kotler dan Amstron (2008: 129).

Sudah banyak hasil penelitian mengenai faktor-faktor yang mempengaruhi proses atau keputusan pembelian. Melalui penelitian ini akan penulis analisis mengenai faktor-faktor yang mempengaruhi terhadap keputusan pembelian Kaos Distro Heuras Genggerong. Desain produk merupakan salah satu faktor individu yang dapat mempengaruhi perilaku pembelian seseorang. Produk Kaos Distro Heuras Genggerong memiliki varian desain produk yang banyak. Sesuai dengan keterangan dari penjaga distronya bahwa sampai saat ini sudah ada lebih dari 60 desain kaos yang dijual oleh Distro Heuras Genggerong.

Seperi dikutip dari laman https://jurnalmanajemen.com/desain-

produk/ bahwa desain produk merupakan proses kreasi sebuah produk yang menggabungkan unsur estetika dan fungsi sehingga bermanfaat dan memiliki nilai tambah. Ini sesuai dengan keterangan dari sang pemilik, bahwa desain produk dari Kaos Distro Heuras Genggerong mengutamakan nilai edukasi, dimana desain produknya terfokus kepada pengenalan ikon dari kota Karawang. Sehingga memunculkan perbedaan produk yang ditawarkan dengan para pesaing.

Selain faktor desain produk, yang dapat mempengaruhi konsumen dalam menentukan keputusan pembelian adalah gaya hidup. Menurut Kotler (2009:175) gaya hidup adalah pola hidup seseorrang di 


\section{SEGMEN Jurnal Manajemen dan Bisnis \\ Volume 17 No 2 juli 2021 \\ p-ISSN: 0216-938X e-ISSN: 2684-8414}

dunia yang tercermin dalam kegiatan, minat, dan pendapat. Keseluruhan diri seseorang dalam berinteraksi dengan lingkungannya digambarkan oleh gaya hidup. Gaya hidup bisa dilihat dari kebiasaan, cara berpakaian dan lain-lain. Penilaian relatif terhadap gaya hidup tergantung penilaian dari orang lain. Dimana gaya hidup adalah bagian dari kebutuhan sekunder, para konsumen juga menempatkan pakaian sebagai kebutuhan sekunder.

Dari definisi tersebut, Kaos Distro Heuras Genggerong juga termasuk bagian dari gaya hidup. Konsumen mempunyai pandangan bahwa Kaos Distro Heuras Genggerong adalah alat untuk pemenuhan gaya hidup. Hal ini yang menjadi faktor konsumen melakukan keputusan pembelian. Dengan menggunakan gaya hidup dengan tepat maka pemasar dapat dibantu untuk memahami perubahan apa saja yang terjadi pada konsumen dan mengetahui bagaimana perilaku konsumen dapat dipengaruhi oleh perubahan tersebut.

Kemampuan Distro Heuras Genggerong dalam mendesain produk dan memenuhi kebutuhan gaya hidup membuat leputusan pembelian dilakukan oleh konsumen meskipun banyaknya produk yang sama dipasaran ditawarkan oleh para pesaing khususnya di Karawang, sehingga penulis mempunyai alasan untuk melakukan penelitian dengan judul "Pengaruh Desain Produk dan Gaya Hidup Terhadap Keputusan Pembelian Kaos Distro Heuras Genggerong Di Karawang"
Berdasarkan latar belakang yang sudah penulis jelaskan, maka perumusan masalah dalam penelitian ini adalah

1. Bagaimana Desain Produk pada Distro Heuras Genggerong Karawang?

2. Bagaimana Gaya Hidup pada konsumen Distro Heuras Genggerong Karawang?

3. Bagaimana Keputusan Pembelian pada Distro Heuras Genggerong Karawang?

4. Berapa besar hubungan antara Desain Produk dan Gaya Hidup pada Distro Heuras Genggerong Karawang?

5. Berapa besar pengaruh parsial antara Desain Produk dan Gaya Hidup terhadap keputusan pembelian pada Distro Heuras Genggerong Karawang?

6. Seberapa besar pengaruh simultan antara Desain Produk dan Gaya Hidup terhadap keputusan pembelian pada Distro Heuras Genggerong Karawang?

\section{KEPUTUSAN PEMBELIAN}

Keputusan pembelian adalah tindakan dari konsumen untuk mau membeli atau tidak terhadap produk dikemukakan oleh Kotler (2002). Menurut Philip Kotler dan Kevin Lane Keller dalam Intan (2016:5) mengatakan bahwa proses keputusan pembelian merupakan proses dimana konsumen melewati lima tahap yaitu pengenalan masalah, pencarian informasi, evaluasi alternative, keputusan pembelian dan perilaku pasca pembelian, yang dimulai jauh sebelum aktual dilakukan dan memiliki dampak yang lama setelah itu.

\section{DESAIN PRODUK}

Kotler dan Amstrong (2008) menjelaskan bahwa desain produk adalah konsep yang lebih besar dari sekedar gaya. Gaya dapat membosankan atau menarik 


\section{SEGMEN Jurnal Manajemen dan Bisnis \\ Volume 17 No 2 juli 2021 \\ p-ISSN: 0216-938X e-ISSN: 2684-8414}

perhatian dan juga gaya hanya menjelaskan penampilan produk. Desain produk adalah jantungnya sebuah produk bukan hanya sekedar penampilan dari luar. Kotler dan Keller (2009) mengemukakan bahwa desain produk adalah totalitas fiur yang mempengaruhi penampilan, rasa, dan fungsi produk berdasarkan kebutuhan pelanggan. Desain produk adalah suatu pendekatan sistematis untuk mengintegrasikan perencanaan produk dan proses yang berpengaruh, termasuk manufaktur dan pendukungnya dikemukakan oleh Imam Djati Widodo (2005).

\section{GAYA HIDUP}

Nugroho J. Setiadi (2010: 77) mengemukakan bahwa gaya hidup secara luas diidentifikasikan sebagai cara hidup yang diidentifikasikan oleh bagaimana menghabiskan waktu mereka (aktivitas), apa yang mereka anggap penting dalam lingkungannya (ketertarikan), dan apa yang mereka pikirkan tentang diri mereka sendiri dan juga dunia sekitarnya (pendapat). Konsep yang lebih baru dan lebih mudah terukur dibandingkan kepribadian disebut gaya hidup. Sedangkan gaya hidup didefinisikan sebagai pola dimana orang hidup dan menggunakan uang dan waktunya dikemukakan oleh Engel, Blackwell, dan Miniard (1995: 449). Menurut Solomon, (1999: 174) gaya hidup mencerminkan pola konsumsi yang menggambarkan pilihan seseorang bagaimana ia menggunakan waktu dan uang.

Berdasarkan perumusan masalah yang telah diuraikan oleh penulis, maka penulis merumuskan hipotesis sebagai berikut:

1. Desain produk dan gaya hidup serempak berpengaruh positif dan signifikan terhadap keputusan pembelian pada distro Heuras Genggerong.

2. Desain produk berpengaruh positif dan signifikan secara parsial terhadap keputusan pembelian pada distro Heuras Genggerong.

3. Gaya hidup berpengaruh positif dan signifikan secara parsial terhadap keputusan pembelian pada distro Heuras Genggerong.

\section{METODE PENELITIAN}

Penelitian ini bertuan untuk mengetahui pengaruh desain produk dan gaya hidup terhadap keputusan pembelian kaos Distro Heuras Genggerong. Dalam penelitian ini populasinya adalah konsumen Distro Heuras Genggerong. Metode deskriptif dan verifikatif terhadap 100 responden dengan teknik insidental sampling digunakan dalam metode penelitian ini. Kesioner, wawancara, observasi, dan studi pustaka merupakan tipe pengumpulan data yang digunakan oleh penulis. Kualitatif dan kuantitatif merupakan teknik analisis yang digunakan oleh penulis. Analisis kuantitatif menggunakan uji validitas, uji reliabilitas, koefisien korelasi, koefisien determinasi, serta uji signifikasi (uji t dan uji F) dan juga menggunakan bantuan program aplikasi SPSS 25 for Windows. Jenis data primer dan sekunder merupakan keseluruhan data yang akan digunakan dalam penelitian ini. Skala pengukuran yang digunakan adalah skala Likert.

HASIL DAN PEMBAHASAN 


\section{SEGMEN Jurnal Manajemen dan Bisnis \\ Volume 17 No 2 juli 2021 \\ p-ISSN: 0216-938X e-ISSN: 2684-8414}

Hasil penelitian dapat dilihat pada

table 1 berikut ini:

Tabel l.

Hasil Pengujian Hipotesis

\begin{tabular}{|l|l|c|c|c|c|c|}
\hline \multirow{2}{*}{ No. } & \multicolumn{2}{|c|}{ Uji Hipotesis } & \multicolumn{5}{|c|}{ Hasil } \\
\cline { 3 - 6 } & Korelasi & Determinasi & $\mathbf{t}$ hitung & f hitung & $\begin{array}{c}\text { Keterangan } \\
\text { Hipotesis }\end{array}$ \\
\hline 1 & $\begin{array}{l}\text { Desain produk terhadap gaya } \\
\text { hidup }\end{array}$ & 0,670 & & 8,935 & & H0 Ditolak \\
\hline 2 & $\begin{array}{l}\text { Desain produk terhadap } \\
\text { keputusan pembelian }\end{array}$ & 0,261 & $6,81 \%$ & 3,755 & & H0 Ditolak \\
\hline 3 & $\begin{array}{l}\text { Gaya hidup terhdapa keputusan } \\
\text { pembelian }\end{array}$ & 0,665 & $44,22 \%$ & 9,580 & & H0 Ditolak \\
\hline 4 & $\begin{array}{l}\text { Desain produk dan gaya hidup } \\
\text { terhadap keputusan pembelian }\end{array}$ & & $74,2 \%$ & & 139,817 & H0 Ditolak \\
\hline
\end{tabular}

Sumber: Data Diolah dengan SPSS (2020)

Hubungan desain produk $\left(\mathrm{X}_{1}\right)$ dengan gaya hidup $\left(\mathrm{X}_{2}\right)$ mempunyai koefisien korelasi sebesar 0,670 yang berarti mempunyai tingkat hubungan yang kuat, dengan kriteria uji nilai Sig $(0,000)<\alpha$ $(0,10)$ dan thitung $(8,935)>\mathrm{t}$ tabel $(1,29007)$, sehingga Ho ditolak.

Pengaruh parsial desain produk $\left(\mathrm{X}_{1}\right)$ terhadap keputusan pembelian (Y) sebesar 0,261 atau 26,1\% dengan kriteria uji $\mathrm{Sig}$ $(0,000)<\alpha(0,10)$ dan $t_{\text {hitung }}(3,755)>\mathrm{t}_{\text {tabel }}$ $(1,29007)$, sehingga Ho ditolak dan gaya hidup $\left(\mathrm{X}_{2}\right)$ terhadap keputusan pembelian (Y) adalah sebesar 0,665 atau $66,5 \%$ dengan kriteria uji sig $(0,000)<\alpha(0,10)$ dan $t_{\text {hitung }}(9,580)>t$ tabel $(1,29007)$, sehingga Ho ditolak. Jadi, 0,665 > 0,261 dapat disimpulkan bahwa variabel gaya hidup lebih berpengaruh terhadap keputusan pembelian dibandingkan variabel desain produk.

Peran desain produk $\left(\mathrm{X}_{1}\right)$ dan gaya hidup $\left(\mathrm{X}_{2}\right)$ secara simultan mempunyai pengaruh terhadap keputusan pembelian (Y), dengan kriteria uji nilai $\operatorname{Sig}(0,000)<\alpha$
$(0,10)$ dan $F_{\text {hitung }}(139,817)>F_{\text {tabel }}(2,36)$, sehingga Ho ditolak. Total pengaruh desain produk $\left(\mathrm{X}_{1}\right)$ dan gaya hidup $\left(\mathrm{X}_{2}\right)$ terhadap keputusan pembelian (Y) sebesar 92,6\%. Hal ini berarti desain produk dan gaya hidup mempunyai kontribusi pengaruh sebesar 92,6\% terhadap keputusan pembelian, sedangkan sisanya sebesar 7,4\% merupakan variabel lain yang tidak diteliti. Adapun variabel lain yang tidak diteliti dimungkinkan seperti variabel kualitas produk, citra perusahaan, persepsi harga dan lainnya yang mesti dilakukan penelitian selanjutnya agar mendapatkan informasi yang menyeluruh tentang keputusan pembelian di Distro Heuras Genggerong.

\section{KESIMPULAN}

Kesimpulan yang dapat ditarik dari penelitian ini adalah sebagai berikut:

Hasil pengujian secara simultan (Uji F) bahwa desain produk dan gaya hidup secara bersama-sama mempunyai pengaruh signifikan terhadap keputusan pembelian pada Kaos Distro Heuras Genggerong yang 


\section{SEGMEN Jurnal Manajemen dan Bisnis \\ Volume 17 No 2 juli 2021 \\ p-ISSN: 0216-938X e-ISSN: 2684-8414}

bisa dilihat dari nilai $\mathrm{F}$ hitung $>\mathrm{F}$ tabel $139,817>2$ yang artinya $\mathrm{H} 0$ ditolak dan $\mathrm{H} 1$ diterima sehingga terdapat pengaruh yang signifikan dan positif dari seluruh variabel secara serempak dari independen yaitu: desain produk dan gaya hidup terhadap keputusan pembelian.

Hasil pengujian secara parsial (Uji t) variabel Desain Produk diperoleh nilai $t$ hitung sebesar 3,755 sedangkan nilai $t$ tabel. Sehingga nilai $\mathrm{t}$ hitung $(3,755)>\mathrm{t}$ tabel $(1,29007)$ dengan tingkat signifikansi sebesar $0,00<0,05$. hal ini menunjukkan bahwa Desain Produk (X1) berpengaruh positif dan signifikan terhadap Keputusan Pembelian (Y) Kaos Distro Heuras Genggerong artinya jika variabel Desain Produk ditingkatkan maka keputusan pembelian akan meningkat. Sehingga dapat disimpulkan bahwa $\mathrm{H} 0$ ditolak dan $\mathrm{H} 1$ diterima.

1. Hasil pengujian secara parsial (Uji t) variabel Gaya Hidup diperoleh nilai $\mathrm{t}$ hitung sebesar 9,580 sedangkan nilai $\mathrm{t}$ tabel . dengan demikian nilai t hitung $(9,580)>\mathrm{t}$ tabel $(1,29007)$ dengan tingkat signifikansi sebesar $0,00<0,05$. hal ini menunjukkan bahwa Gaya Hidup (X2) berpengaruh positif dan signifikan terhadap Keputusan Pembelian (Y) Kaos Distro Heuras Genggerong artinya keputusan pembelian dapat ditingkatkan apabila variabel gaya hidup meningkat. Maka kesimpulannya $\mathrm{H} 0$ ditolak dan $\mathrm{H} 1$ diterima.

2. Hasil Uji Koefisien Determinasi $\left(\mathrm{R}^{2}\right)$ menunjukkan bahwa 0,737 berarti $73,7 \%$ variabel Keputusan Pembelian dapat dijelaskan oleh desain produk dan gaya hidup. Sedangkan 26,3\% lainnya dijelaskan oleh variabel lain yang tidak dibahas dalam penelitian ini

\section{DAFTAR PUSTAKA}

Ali Ghufran Basa (2017). Pengaruh Kualitas Produk, Citra Merek dan Gaya Hidup Terhadap Keputusan Pembelian Sepatu Merek New Balance Pada Mahasiswa Fakultas Ekonomi Dan Bisnis Universitas Sumatera Utara

Alma, Buchari. 2011. Manajemen Pemasaran dan Pemasaran Jasa. Bandung : Alfabeta

Assauri, Sofjan (2015). Manajemen Pemasaran. Depok : PT Rajagrafindo Persada.

Fahma Ilmaya (2011). Analisis Pengaruh Interaksi Harga dan Desain Produk Terhadap Keputusan Pembelian Batik Di Eka Batik Semarang.

Harmaita, Ida Ayu (2014). Pengaruh Gaya Hidup Terhadap Keputusan Pembelian Handphone Blackberry. (Studi Kasus pada Mahasiswa Fakultas Ekonomi dan Bisnis Universitas Mercubuana)

Kotler, Philip dan Gary Kevin Lane Keller.2008. Manajemen Pemasaran. Jakarta : Erlangga.

Kotler, Philip dan Gary Kevin Lane Keller.2009. Manajemen Pemasaran. Edisi 12 Jilid 1. Jakarta : Erlangga.

Kotler, Philip dan Gary Amstrong. 2009. Principles Of Marketing. Edisi 13 Jilid1. Jakarta : Erlangga.

Linda Aprianti (2018). Pengaruh Gaya Hidup dan Customer Experience Terhadap Keputusan Pembelian 


\section{SEGMEN Jurnal Manajemen dan Bisnis \\ Volume 17 No 2 juli 2021 \\ p-ISSN: 0216-938X e-ISSN: 2684-8414}

Pada Dunkin' Donuts Cabang

Karawang.

Sugiyono. 2012. Metode Kuantitaif, Kualitatif, dan R\&D. Bandung : Alfabeta.

Sumarwan, Ujang. 2015. Perilaku Konsumen. Edisi 3. Bogor : Ghalia Indonesia.

Swasta, Basu dan T Hani Handoko. 2000. Manajemen Pemasaran: Analisa dan Perilaku Konsumen. Yogyakarta: BPFE.

Syahrul Riadul Fikri (2019). Pengaruh Gaya Hidup dan Persepsi Kualitas Terhadap Keputusan Pembelian Smartphone Merek Xiaomi Pada Mahasiswa Fakultas Bisnis dan Ilmu Sosial Universitas Buana Perjuangan Karawang. 